\title{
Financial Impact of Irrigation and Nitrogen: Topdressing in Rural Enterprises of Sugarcane in Uruaçu, Brazil
}

\author{
Gabriela Nobre Cunha ${ }^{1} \&$ Antonio Pasqualetto ${ }^{1}$ \\ ${ }^{1}$ Department Territorial Planning and Development, Pontifical Catholic University of Goiás - PUC, Goiânia, Brazil \\ Correspondence: Gabriela Nobre Cunha, Department Territorial Planning and Development, Pontifical Catholic \\ University of Goiás- PUC, Av. Universitária 1.440, Setor Universitário, Goiânia, Brazil. Tel: 55-62-3946-1000
}

Received: May 5, 2020

doi:10.5430/ijba.v11n4p21
Accepted: June 8, 2020

Online Published: June 11, 2020

URL: https://doi.org/10.5430/ijba.v11n4p21

\begin{abstract}
The success of a project depends on a good planning of activities focused on increasing yield and minimizing production costs. The objective of the present work was to assess the economic viability of irrigated sugarcane crops (plant crop and ratoon crop) under nitrogen topdressing, in northern state of Goiás (GO), Brazil. The data needed for the research were obtained in a sugarcane crop area in the Estrela do Lago Farm, which belongs to the Uruaçu industry, in the municipality of Uruaçu, GO. The CTC4 sugarcane variety was used, which has high tillering and yield, and great adaptability to mechanized planting and harvest. The sugarcane was planted in double rows spaced $1.80 \mathrm{~m}$ apart. The total nitrogen topdressing rate $\left(100 \mathrm{Kg} \mathrm{ha}^{-1}\right)$ was divided into three applications with 60-day intervals during the crop development. The costs were obtained based on the following items: mechanized operations; manual operations; consumed material, and other expenses. The production cost was calculated using the total production operational cost structure used by the Brazilian Institute of Agricultural Economy. The highest costs for sugarcane in plant crop, with and without nitrogen topdressing, are due to mechanized operations and consumed material, which reached approximately $60 \%$ of the costs.
\end{abstract}

Keywords: Saccharum officinarum L. yield, cost, fertilization

\section{Introduction}

Sugarcane is one of the main crops grown in Brazil, standing out due to its planted area and production volume and value. The great interest for this crop production is due to the increasing value of its derivatives and the economic importance of sugar and ethanol (Anjos et al., 2008). Brazil is currently the greatest sugarcane producing country, followed by India and China, and represents approximately $40 \%$ of the international sugar trade (Agrianual, 2010). São Paulo is the highest producing state (52.6\%), followed by Minas Gerais (9.0\%), Goiás (8.0\%), Paraná (7.3\%), Mato Grosso do Sul (5.7\%), Alagoas (5.4\%), and Pernambuco (3.8\%) (Conab, 2011).

The sugarcane agroindustry is searching for a higher agricultural and industrial efficiencies, focused on high technology and profit (Bacha, 2012; Unica, 2013).

The sugarcane economy is focused on a rational use of agricultural production resources, and distribution and consumption of goods and services of the sugarcane agrobusiness, which comprises the crop products and by-products; therefore, the sugarcane economy seeks for solutions of economic problems of the sector, such as purchases, sells, and taxations, and for management of the crop and its products - clean energy, sugar, cachaca, cellulose, molasses, vinasse, and others (Renner, 2004; Ambiente Brasil, 2006; Alves, 2011).

Nitrogen fertilizers present unfavorable characteristics for the sugar-energy sector by increasing production costs and requiring high amount of fossil fuels for their production; thus, assessing the cost to benefit ratio of nitrogen application correlated with the fertilizer efficiency is important, since the urea, which is the most common nitrogen source in the world, currently presents high losses, mainly by volatilization (Schultz, 2012).

Irrigated sugarcane crops depend on several factors, such as amount of water and fertilizer to be applied (Dantas Neto et al., 2006), irrigation management (Ramesh et al., 1994), cultivar, age at cut, soil type, and climate (Smit \& Singels, 2006).

The irrigated sugarcane has direct benefits, such as increases in yield and ratoon longevity; and indirect benefits, such as decreases in production costs (Matioli et al., 1996). Culm yield is affected by water deficiency; thus, 
irrigation is an alternative technic for reaching high yields. Gava et al. (2011) evaluated drip irrigation for three sugarcane cultivars and found mean increases of $20 \%$ in plant crop, and $28 \%$ in ratoon crop, when using irrigation.

Information on production costs of sugar-energy sector is little consistent because there are few works on this issue and no methodology to assess costs that are common to the several industrial plants (Marques, 2009). When applied properly, procedures for measuring sugarcane production costs can show the main components that limit or boost the financial performance (Oliveira et al., 2015).

The success of a project depends on a good planning of activities focused on increasing yield and minimizing production costs (Rapassi et al. 2008).

In this context, the objective of this work was to assess the economic viability of irrigated sugarcane crops (plant crop and ratoon crop) under nitrogen topdressing, in northern state of Goiás (GO), Brazil.

\section{Method}

The data needed for the research were obtained in a sugarcane crop area in the Estrela do Lago Farm, which belongs to the Uruaçu industry, in the municipality of Uruaçu, GO, Brazil $\left(14^{\circ} 31^{\prime} 29^{\prime \prime} \mathrm{S}\right.$ and $49^{\circ} 08^{\prime} 27^{\prime \prime} \mathrm{W}$, and mean altitude of $520 \mathrm{~m}$ ). The soil of the area was classified as dystrophic Typic Hapludox (Embrapa, 2013). The local climate is Aw, tropical, according to the classification of Köppen and Geiger (1928), presenting less rainfall in the winter than in the summer, mean temperature of $25^{\circ} \mathrm{C}$, and mean annual rainfall depths reaching $1,638 \mathrm{~mm}$, but poorly distributed throughout the year.

The CTC4 sugarcane variety was used, which has high tillering and yield, and great adaptability to mechanized planting and harvest.

The sugarcane was planted in double rows spaced $1.80 \mathrm{~m}$ apart, with $0.50 \mathrm{~m}$ between plants. The dripper lines were buried $0.20 \mathrm{~m}$ into the soil between the double rows. These dripper lines presented the following characteristics: thin wall, service pressure of $1.0 \mathrm{bar}$, flow of $2.0 \mathrm{~L} \mathrm{~h}^{-1}$, and spacing between drippers of $0.50 \mathrm{~m}$.

Soil planting fertilization was applied in the furrows and consisted of $30 \mathrm{~kg}$ of N ha ${ }^{-1}$ (urea), $120 \mathrm{~kg}$ of $\mathrm{P}_{2} \mathrm{O}_{5} \mathrm{ha}^{-1}$ (simple superphosphate), and $80 \mathrm{~kg}$ of $\mathrm{K}_{2} \mathrm{O} \mathrm{ha}^{-1}$ (potassium chloride). The total nitrogen topdressing rate (100 $\mathrm{Kg}$ $\mathrm{ha}^{-1}$ ) was divided into three applications with 60-day intervals during the crop development.

The culm yield $\left(\mathrm{Mg} \mathrm{ha}^{-1}\right)$ was obtained by the mean of the sampled area (10 ha).

The costs were obtained based on the following items:

a) Mechanized operations: machinery working hours; tractor working days for distribution of the setts at planting; distance $(\mathrm{km})$ ran by trucks to transport the setts to the planting site; and cost for the execution of these operations, according to the prices paid by the producer;

b) Manual operations: number of men working days to execute the operations, multiplied by the mean value for the region;

c) Consumed materials: obtained by multiplying the quantity of material used by their respective prices in the region;

d) Other expenses: a 9\% rate of total expenses with technical assistance and interests was considered.

Herbicides were applied using a 121-cv tractor with front wheel assist $(4 \times 2$ FWA $)$ and a sprayer with capacity for $600 \mathrm{~L}$ of solution. The soil was prepared using a harrowing $(14 \times 26 ")$ and a leveling harrowing $(28 \times 22 ")$, both pulled by a $121-\mathrm{cv} 4 \times 2$ FWA tractor.

Limestone was applied using a distributor with capacity for $2 \mathrm{~m} 3$. The beds were raised using a drag type leveling disc harrow with 16 discs; and furrows were opened using a 2-point furrower, with a soil fertilizer distributor with capacity of $300 \mathrm{~kg}$ per point. The beds and furrows were done using a 121-cv $4 \times 2 \mathrm{FWA}$ tractor.

The setts were transported in a truck. The setts were distributed during the planting using 4-wheel trailers adapted with stanchion and pulled by $75-\mathrm{cv}$ tractors. The covering operation was done using a two-row coverer, with a $200-\mathrm{L}$ tank for pesticides.

The two cuts of the sugarcane crop (plant crop and ratoon crop) were considered for the economic analysis, using the culm yield and total recoverable sugar (TRS) yield for rainfed crops, with and without nitrogen topdressing, and for irrigated crop.

The estimated price of $1 \mathrm{~kg}$ of TRS was R (BRL) 0.56 (mean of the 2018 and 2019 crop season). The production cost was calculated using the total production operational cost structure used by the Brazilian Institute of Agricultural Economy, proposed by Matsunaga et al. (1976). 


\section{Results and Discussion}

The mean yields were 112.6 and $93.3 \mathrm{Mg} \mathrm{ha}^{-1}$ in the first cut, and 77.4 and $70.4 \mathrm{Mg} \mathrm{ha}^{-1}$ in the second cut, with and without nitrogen topdressing, respectively. The irrigated sugarcane mean yield were 137.38 and of $109.5 \mathrm{Mg} \mathrm{ha}^{-1}$ for the plant crop and ratoon crop, respectively. These means were similar to those found by Gava et al. (2011), who found mean culm yields of $106.5 \mathrm{Mg} \mathrm{ha}^{-1}$ in first cycle for rainfed management, and $132.2 \mathrm{Mg} \mathrm{ha}^{-1}$ for irrigated management.

Increasing the production scale is a relevant tool to decrease costs and increase the commercial attractivity of sugarcane production; this increase is from yield gains without the need for increases in area (Zilio \& Lima, 2015).

The TRS yields from the culms were 137.4 and of $136.1 \mathrm{~kg} \mathrm{Mg}^{-1}$ in the first cycle, and 133.7 and $132.3 \mathrm{~kg} \mathrm{Mg}^{-1}$ in the second cycle, with and without nitrogen topdressing, respectively. The mean TRS yields of the irrigated sugarcane were 138.6 and $134.3 \mathrm{Mg} \mathrm{ha}^{-1}$ for the plant crop and ratoon crop, respectively.

According to Pereira et al. (2015a), the variables that impact the most the net present value of sugarcane are the yield and the TRS content, which indicate the need for detailed analyses of the management practices used, because these indexes can be improved by using adequate technologies, although they are affected by climate conditions.

The sugarcane presented good quality and TRS yield above the average, which is $121.96 \mathrm{~kg} \mathrm{Mg}^{-1}$. Quintana et al. (2012), found a mean TRS yield of $128.65 \mathrm{~kg} \mathrm{Mg}^{-1}$ in 4.677 .19 ha of commercial sugarcane crops, regardless of the sugarcane variety, age, and type of harvest.

The costs of mechanized operations and manual operations for sugarcane in plant crop were $94.45 \%$ and $85.71 \%$ higher than those in ratoon crop, with and without nitrogen topdressing. The nitrogen topdressing presented no expressive effect on the costs of mechanized operations and manual operations (Figure 1A and 1B).

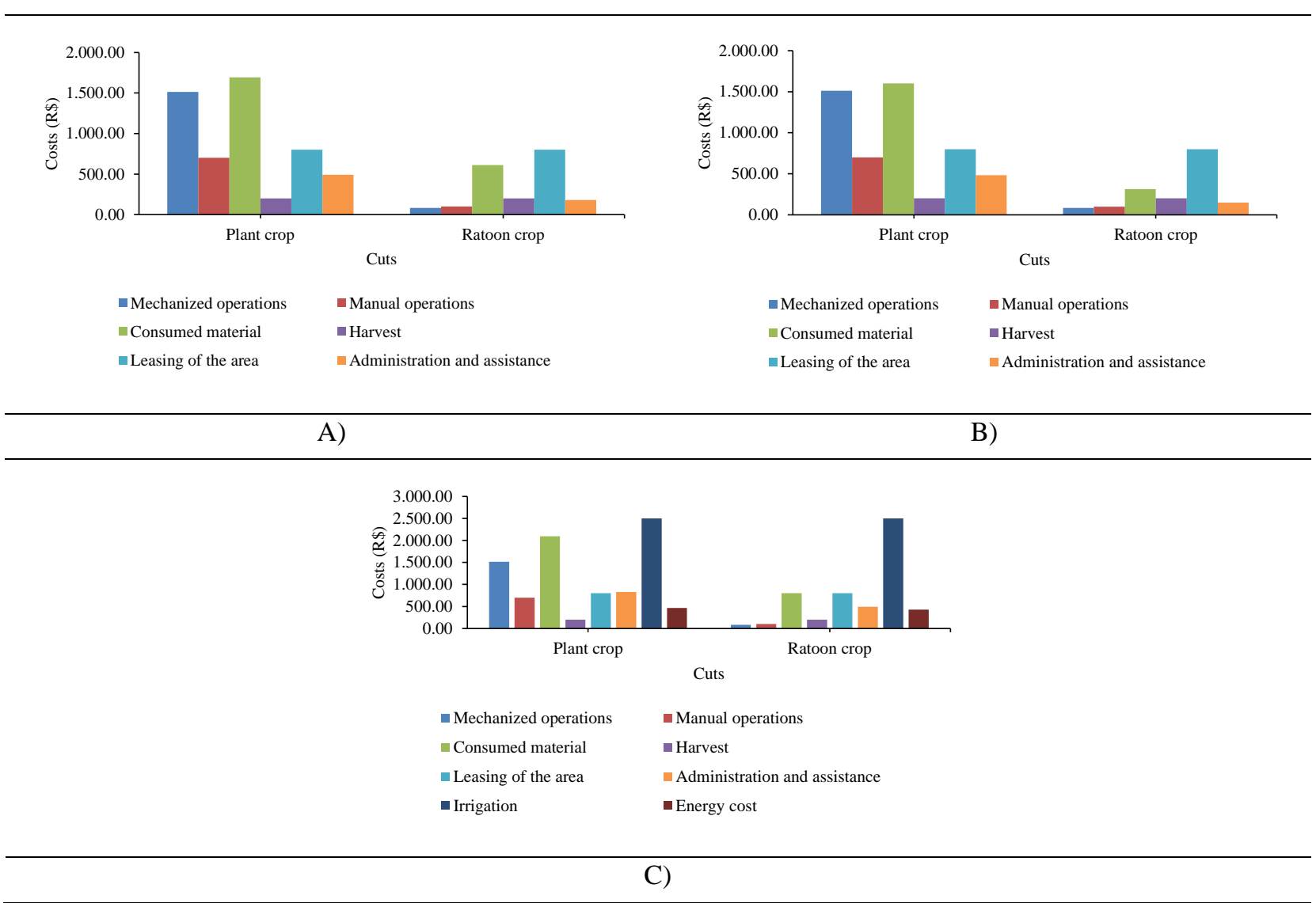

Figure 1. Costs of sugarcane crops as a function of cuts; crops with (A) and without nitrogen topdressing (B) and with irrigation $(\mathrm{C})$ 
Input price is continuouslyincreased, besides that farmers are facing the problemof input availability at proper time, inadequate quantityand with time taking marketing process of the caneuntimely and late payment of the produce by the sugarmills (Kumar et al., 2014). The use of the nitrogen fertilizer increases the production costs, but also increases the culm yield, resulting in higher profitability, and can assist in increasing the ratoon longevity, reducing financial costs and environmental impacts related to soil preparation and planting operations (Joris, 2015).

The consumed material costs of the sugarcane crops, with and without nitrogen topdressing, in plant crop was $63.81 \%$ and $80.43 \%$ higher than those in the ratoon crop, respectively. The consumed material costs of the sugarcane in plant crop, with nitrogen topdressing, was 5.32\% higher than that in the crop without nitrogen topdressing. The consumed material costs of the sugarcane in ratoon crop with nitrogen topdressing was $48.80 \%$ higher than those found without nitrogen topdressing.

The planning and decision making of the producer should consider strong and weak points of the crop and the control of the total crop cost, since the crop production cost is essential for the management of rural entrepreneurships (Andrade et al., 2017).

The costs associated with harvest and leasing of the area for the sugarcane crops, with and without nitrogen topdressing, in the first year (plant crop) was practically the same in the second year (ratoon crop). Partnerships for leasing of areas for planting and harvesting, which demand investments and structural acquisitions, are more advantageous, in terms of costs, than partnerships with raw material suppliers (Souza \& Cleps, 2009; Trevisan et al., 2017).

Administration and technical assistance costs of sugarcane crops, with and without nitrogen topdressing, in plant crop was $63.38 \%$ and $68.90 \%$ higher than those in ratoon crop, respectively. The administration and technical assistance costs in the sugarcane with nitrogen topdressing were $1.83 \%$ higher than those without nitrogen topdressing in plant crop; and these costs, with nitrogen topdressing, were $16.63 \%$ higher than those without nitrogen topdressing in ratoon crop.

Costs with inputs and labor for implementation, conduction, and renovation of sugarcane crops represent the highest part of the total annual cost (Pereira et al., 2015b). Verma and Solanki (2020) noted that total variable cost was increasing with respect to the farm size, thus, thereforethe total cost of cultivation was increasing with respect to farm size holding due to bigger farmers could incurred more expenditure on the material inputs.

The costs with consumed material, and administration and technical assistance of the sugarcane in plant crop were $61.60 \%$ and $40.60 \%$ higher than those in ratoon crop, when using irrigation (Figure 1C). The other costs had practically no variation due to sugarcane irrigation (Figure 1A).

Implementation of irrigation methods with reduced costs is dependent on the need, and crop and soil conditions; the producers should establish the criteria to be used, according to their interests and conditions based on internal and external factors (Amorim et al., 2007).

The costs of mechanized operations, manual operations, consumed material, harvest, leasing of the area, and administration and technical assistance represented $28.04 \%, 12.97 \%, 31.36 \%, 3.71 \%, 14.83 \%$, and $9.09 \%$ of total the operational costs of the sugarcane crop (plant crop) with nitrogen topdressing, respectively (Figure 2A); these costs were similar to those found for the crop without nitrogen topdressing (Figure 2B). The estimation of costs is related to technology management, i.e., to an efficient allocation of productive resources and information on prices of these resources (Reis, 2007).
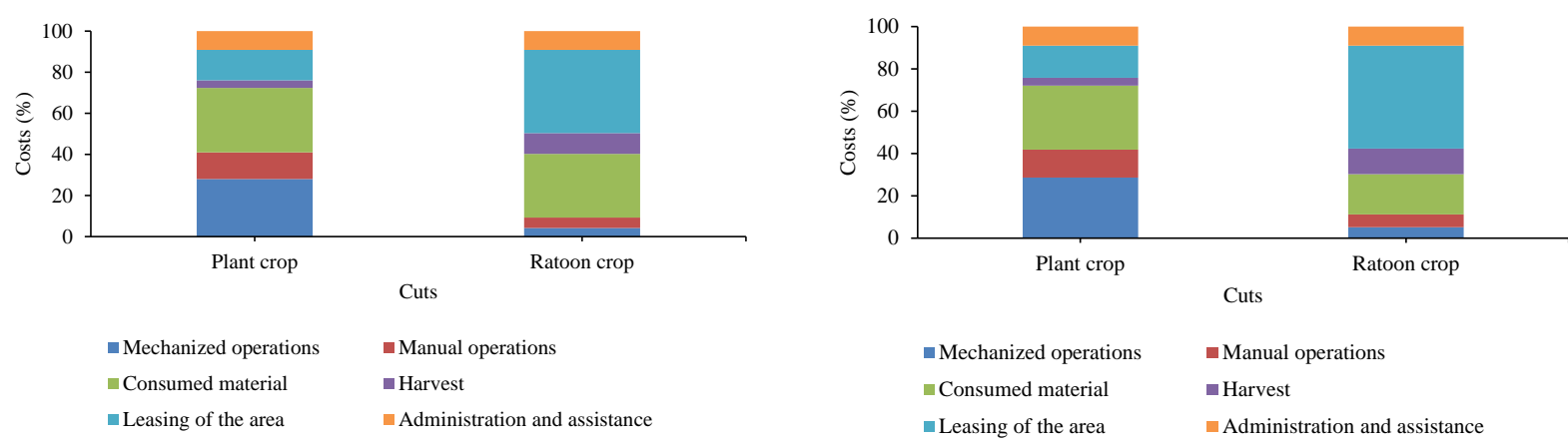

A)

B) 


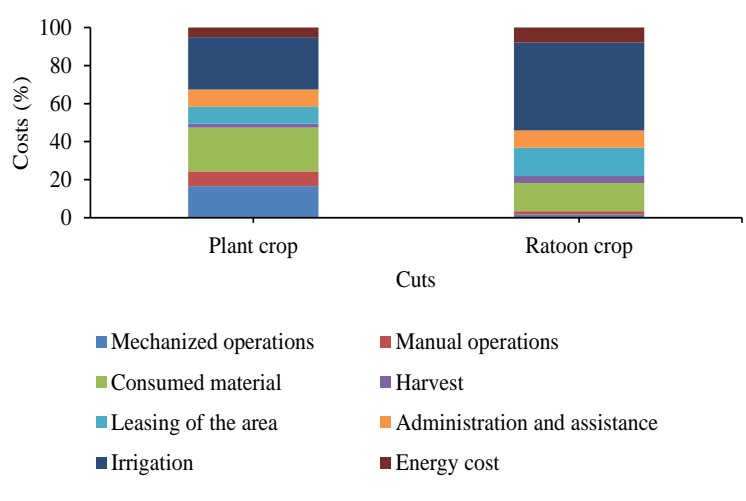

C)

Figure 2. Percentual costs of sugarcane crop as a function of cuts; crops with (A) and without nitrogen topdressing (B) and with irrigation (C)

Pokharel et al. (2019) observed that price fixation based on the recovery rate will be the viable option over prevailing weight-based system so that sugar mill will seek profitable techniques to increase the recovery percent and farmers will also seek for the good management practices to increase the efficiency of the farm along with increment in the productivity through obtainable timely supply of inputs (setts, manures and fertilizers).

The costs of mechanized operations, manual operations, consumed material, harvest, leasing of the area, and administration and technical assistance represented 4.25\%, 5.06\%, 30.99\%, 10.12\%, 40.49\%, and 9.09\% of the total operational cost of the sugarcane crop (ratoon crop) with nitrogen topdressing, respectively (Figure 2A).

The agricultural machinery can represent up to $20 \%$ of the total production cost of crops; increases in costs associated with machinery use are due to the lack of proper dimensioning of the mechanized system, which justifies the need for planning to obtain better return on investment with the machinery performances (Matos, 2007).

The costs of the ratoon crop without nitrogen topdressing were different from those of the plant crop, which were $5.10 \%, 6.07 \%, 19.03 \%, 12.14 \%, 48.57 \%$, and $9.09 \%$ for mechanized operations, manual operations, consumed material, harvest, leasing of the area, and administration and technical assistance, respectively (Figure 2B).

Decrease in yield over cuts of crops is a great challenge for sugarcane production, which compromises the return on investment standards required, since after the first cut, a larger sugarcane area is required for the activity, the land is underused, and the activity become less efficient because of increases in costs for transport of the sugarcane from the production area to the industry (Neves, 2008).

The costs of mechanized operations, manual operations, consumed material, harvest, leasing of the area, and administration and technical assistance, irrigation, and electrical energy represented $16.63 \%, 7.69 \%, 23.00 \%, 2.20 \%$, $8.79 \%, 9.09 \%, 27.48 \%$, and $5.13 \%$ of the total operational cost of the irrigated sugarcane crop (plant crop), respectively; whereas the costs for the ratoon crop were $1.55 \%, 1.85 \%, 14.87 \%, 3.70 \%, 14.80 \%, 9.09 \%, 46.26 \%$ and $7.88 \%$, respectively. The higher percentual costs with irrigation in the ratoon crop were mainly due to a general decrease in production costs in ratoon crop, consequently, this was not found for irrigation costs, which were continuously high (Figure 2C).

Campos et al. (2017) found that operational costs (variables) of irrigated sugarcane crops had the highest impact on the production costs, especially labor and electrical energy; and that this denotes the potential result that a management of control can bring to the project, since this can reduce the need for electrical energy and labor and decrease costs.

The total cost of the sugarcane crops, with and without nitrogen topdressing, were $44.90 \%$ and $44.53 \%$ of the gross income for the plant crop, and $17.26 \%$ and $14.98 \%$ of the gross income for the ratoon crop, respectively. Consequently, the net income of the sugarcane crops, with and without nitrogen topdressing, were $55.14 \%$ and $55.47 \%$ of the gross income for the plant crop, and $82.73 \%$ and $85.02 \%$ of the gross income for the ratoon crop, respectively, representing a significant increase in net income (Figure 3A and $3 \mathrm{~B}$ ). 

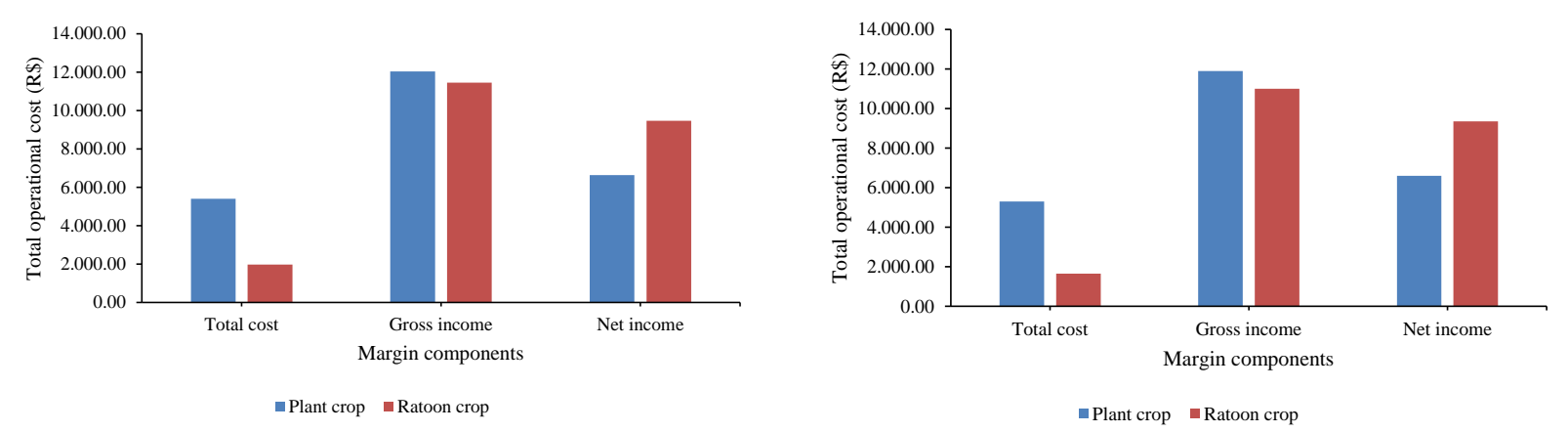

A)

B)

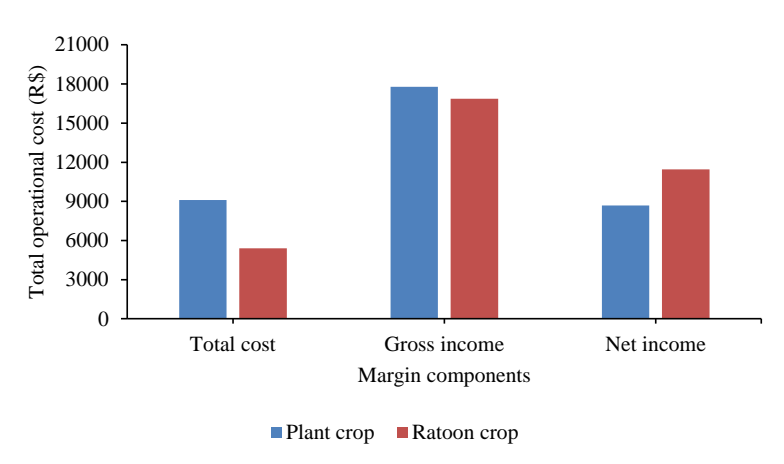

C)

Figure 3. Total operational cost of sugarcane crops as a function of margin components; crops with (A) and without nitrogen topdressing (B) and with irrigation (C)

Perina (2017) found similar results, with implementation cost of R\$ (BRL) 5,892.64 per hectare of sugarcane. The total implementation cost of a traditional sugarcane crop (systematized for mechanized harvest) varies from R \$ (BRL) 4,500.00 to R \$ (BRL) 6,000.00 (Sant'ana et al., 2009; Moreira \& Bonizio, 2012); and in traditional Brazilian Center-South regions, the mean sugarcane production cost is approximately R $\$$ (BRL) 5,297.08 (PECEGE/CNA, 2012).

The total costs of the sugarcane crops, with and without nitrogen topdressing, were $18.66 \%$ and $19.73 \%$ lower than the net income for the plant crop, and $79.13 \%$ and $82.38 \%$ for the ratoon crop, respectively. This explains the high net income obtained in the ratoon crop, whose costs were suppressed due to the fewer activities after the first crop year, in which the costs are higher due to activities related to sugarcane planting and/or reform. The implementation of a sugarcane crop (plant crop) has the highest cost percentage, since operation of planting and acquisition of setts and inputs are expensive in the first year (Santos et al., 2016).

Kaneko et al. (2009) found a total cost of R\$ (BRL) 2,677.50 for a sugarcane crop (ratoon crop) in rainfed conditions, with nitrogen topdressing.

The total cost of the irrigated sugarcane crops in plant crop and ratoon crop, were $51.16 \%$ and $32.05 \%$ of the gross income, respectively. Consequently, the net income of irrigated sugarcane in plant crop and ratoon crop were 48.84\% and $67.95 \%$ of the gross income, respectively (Figure 3C). The financial control intends to maximize crop yield and, thus, the profits, and minimize production costs based on the identification and elimination of possible causes of decreases in yield (Liu et al., 2006).

It is concluded that the higher costs of sugarcane crops in plant crop, with and without nitrogen topdressing, are due to mechanized operations and consumed material, totaling approximately $60 \%$ of the total costs.

A great part of the costs of irrigated sugarcane crops (plant crop) is related to irrigation (technical assistance, irrigation, and electrical energy), representing $42 \%$ of the total costs. 
The total cost of sugarcane crops, with and without nitrogen topdressing, represented $45 \%$ of the gross income for the plant crop, and up to $17.26 \%$ of the gross income for the ratoon crop.

The net income of irrigated sugarcane crop represented at least $48.84 \%$ of the gross income.

\section{Acknowledgements}

The authors thank the Pontifical Catholic University of Goiás (PUC) for supporting research.

\section{References}

Agrianual. (2010). Agrianual 2011: anuário da agricultura brasileira. São Paulo: Informa Economics IEG/FNP.

Alves, L. Q. (2011). Viabilidade econômica dos créditos de $\mathrm{CO}_{2}$ da cana-de-açúcar para produção de aguardente Artesanal. Dissertação (Mestrado). Alfenas: UNIFENAS.

Ambiente Brasil. (2006). Reflorestamento: sequestro de Carbono. Retrieved from http://www.arvoresbrasil.com.br/reflorestamento

Amorim, F. A. M., Amorim, J. N., \& Britto, W. S. F. (2007). Custos de irrigação na cana-de-açúcar: um estudo realizado com os diversos sistemas de irrigação em Juazeiro-BA (pp. 1-15). XIV Congresso Brasileiro de Custos-João Pessoa-PB, Brasil.

Andrade, R. J., Ferrari, J. V., Fracaro, A. A., \& Carvalho, M. C. (2017). Viabilidade econômica da produção de cana-de-açúcar na região de jales (pp. 1-11). I Simpósio Sul-Mato-Grossense de administração.

Anjos, I. A., Silva, D. N., Campana, M. P., In Miranda, L. L. D., Vasconcelos, A. C., \& Landell, M. G. de A. (2008). Cana-de-açúcar. Campinas: Instituto Agronômico.

Bacha, C. J. C. (2012). Economia e política agrícola no Brasil (2nd ed.). São Paulo: Atlas.

Campos, F. H., Bigaton, A., Silva, H. J. T., Marques, P. V., \& Coelho, R. D. (2017). Análise de rentabilidade de irrigação na cana-de-açúcar: estudo de caso de uma usina de Goiás. Rev. iPecege, 3(2), 124-133. https://doi.org/10.22167/r.ipecege.2017.2.124

Conab. (2011). Séries históricas relativas às safras 1976/77 a 2013/14 de área plantada, produtividade e produção. Companhia Nacional Do Abastecimento. Retrieved from http://www.conab.gov.br/conteudos.php? $a=1252 \& t=$

Dantas Neto, J., Figueirêdo, J. L. C., Farias, C. H. A., Azevedo, H. M., \& Azevedo, C. A. V. (2006). Resposta da cana-de-açúcar, primeira soca, a níveis de irrigação e adubação de cobertura. Revista Brasileira de Engenharia Agrícola e Ambiental, 10(2), 283-288. http://doi.org/10.1590/S1415-43662006000200006

Embrapa. (2013). Sistema brasileiro de classificação de solos. Empresa brasileira de pesquisa agropecuária (2nd ed.). Rio de Janeiro: Ministério da Agricultura e do abastecimento.

Gava, G. J. C., Silva, M. A., Silva, R. C., Jeronimo, E. M., Cruz, J. C. S., \& Kölln, O. T. (2011). Produtividade de três cultivares de cana-de-açúcar sob manejos de sequeiro e irrigado por gotejamento. Revista Brasileira de Engenharia Agrícola e Ambiental, 15(3), 250-255. http://doi.org/10.1590/S1415-43662011000300005

Joris, H. A. W. (2015). Nitrogênio na produção de cana-de-açúcar: aspectos agronômicos e ambientais. Tese (Doutorado). Instituto Agronômico-IAC. Campinas, SP.

Kaneko, F. H., Tarsitano, M. A. A., Rapassi, R. M. A., Chioderoli, C. A., \& Nakayama, F. T. (2009). Análise econômica da produção de cana-de-açúcar considerando-se a terceirização das operações agrícolas: o caso de um produtor. Pesquisa Agropecuária Tropical, Goiânia, 39(3), 266-270. https://doi.org/10.5216/pat.v39i3.6017

Köppen, W., \& Geiger, R. (1928). Klimate der Erde. Gotha: Verlag Justus Perthes.

Kumar, T., Singh, H. L., Jawla, S. K., \& Sachan, S. (2014). Cost and Returns of Sugarcane Production at Different Size Groups of Farmsin District Meerut (U. P.), India. Annals of Agri-Bio Research, 19(3), 561-565.

Liu, T. L., Juang, K. W., \& Lee, D. Y. (2006). Interpolating soil properties using kriging combined with categorical information of soil maps. Soil Science Society of America Journal, 70(4), 1200-1209. https://doi.org/10.2136/sssaj2005.0126

Marques, P. V. (2009). Custo de produção agrícola e industrial de açúcar e álcool no Brasil na safra 2007/2008. Relatório apresentado a Confederação da Agricultura e Pecuária do Brasil - CNA. Piracicaba: Universidade de São Paulo, Escola Superior de Agricultura "Luiz de Queiroz". 
Matioli, C. S., Peres, F. C., \& Frizzone, J. A. (1996). Análise de decisão sobre a viabilidade da irrigação suplementar de cana-de-açúcar colhida no mês de julho na região de Ribeirão Preto - SP. In Congresso Brasileiro De Engenharia Agrícola. Bauru.Resumos Jaboticabal: Associação Brasileira de Engenharia Agrícola.

Matos, M. A. (2007). Modelo informatizado para o planejamento operacional e econômico de sistemas mecanizados com a consideração da pontualidade. Dissertação (Mestrado). Escola Superior de Agricultura "Luiz de Queiroz", Piracicaba.

Matsunaga, M., Bemelmans, P. F., Toledo, P. E. N., Dulley, R. D., Okawa, H., \& Pedroso, I. A. (1976). Metodologia de custo de produção utilizada pelo IEA. Agricultura em São Paulo, São Paulo, 23(1), 123-139.

Moreira, M. G., \& Bonizio, R. C. (2012). Análise comparativa dos custos de cana-de-açúcar: produção independente x usina de açúcar e álcool. Custos e @ gronegócio on line, 8(2), 84-99.

Neves, M. F. (2008). Desafios da produção de cana-de-açúcar. Retrieved from http://www.favaneves.org/arquivos/1-producao-cana.pdf

Oliveira, C. O., Lazarini, E., Tarsitano, M. A. A., Pinto, C. C., \& Sá, M. E. (2015). Custo e lucratividade da produção de sementes de soja enriquecidas com molibdênio. Pesquisa Agropecuária Tropical, 45(1), 82-88. http://doi.org/10.1590/1983-40632015v4527961

PECEGE. (2012). Custos de produção de cana-de-açúcar, açúcar e etanol no Brasil: acompanhamento da safra 2011/2012 - Centro-Sul. Piracicaba: Universidade de São Paulo, Escola Superior de Agricultura "Luiz de Queiroz".

Pereira, G. G. S., Albrecht, A. J. P., Fausto, D. A., \& Migliavacca, R. A. (2015a). Custo de produção de cana-de-açúcar no Estado do Mato Grosso do Sul. Revista iPecege, 1(1), 81-102. https://doi.org/10.22167/r.ipecege.2015.1.81

Pereira, R. M., Alves Junior, J., Casaroli, D., Sales, D. L., Rodriguez, W. D. M., \& Souza, J. M. F. (2015b). Viabilidade econômica da irrigação de cana-de-açúcar no cerrado brasileiro. Irriga, Botucatu, Edição Especial, Irriga \& Inovagri, 1(2), 149-157. https://doi.org/10.15809/irriga.2015v1n2p149

Perina, O. T. (2017). Análise de viabilidade técnica e econômica de diferentes métodos de implantação de canaviais em relação ao método inter-rotacional. Escola Superior de Agricultura "Luiz de Queiroz", Piracicaba.

Pokharel, D., Uprety, R., Mehata, S., Shrestha, H. K., \& Panday, D. (2019). Dynamics and Economic Analysis of Sugarcane Production in Eastern Plains of Nepal. Current Agriculture Research Journal, 7(2), 201-212. https://doi.org/10.12944/CARJ.7.2.08

Quintana, K. A., Zanini, J. R., \& Silva, E. R. (2012). Irrigação e fertirrigação por gotejamento em cana-de-açúcar na $\begin{array}{lllll}\text { presença } & \text { ausência de boro. } & \text { Científica, } & 40(2), & 103-116 .\end{array}$ http://doi.org/10.15361/1984-5529.2012v40n2p103+-+116

Ramesh, P., Kailasam, C., \& Srinivasan, T. R. (1994). Performance of sugarcane (Saccharum officinarum L) under surface drip, sub surface drip (biwall) and furrow methods of irrigation. Journal of Agronomy and Crop Science, 172, 237-241. https://doi.org/10.1111/j.1439-037X.1994.tb00173.x

Rapassi, R. M. A., Tarsitano, M. A. A., Pereira, J. C. R., \& Araujo, C. A. M. (2008). Cultura do eucalipto na região de Suzanápolis Estado de São Paulo: análise econômica. Informações Econômicas, São Paulo, 38(4), 7-13.

Reis, R. P. (2007). Fundamentos de economia aplicada. Lavras: UFLA/FAEPE.

Renner, R. M. (2004). Sequestro de carbono e a viabilização de novos reflorestamentos no Brasil. Dissertação (Mestrado). Universidade Federal do Paraná, Curitiba - PR.

Sant'anna, S. A. C., Fernandes, M. F., Ivo, W. M. P. M., \& Costa, J. L. S. (2009). Evaluation of soil quality indicators in sugarcane management in sandy loam soil. Pedosphere, 19, 312-322. https://doi.org/10.1016/S1002-0160(09)60122-3

Santos, D. F. L., Mendes, C. C., Farinelli, J. B. M., \& Farinelli, R. (2016). Viabilidade econômica e financeira na produção de cana-de-açúcar em pequenas propriedades rurais. Custos e @ gronegócio on line, 12(4), 222-254.

Schultz, N. (2012). Fixação biológica de nitrogênio associada à cultura de cana de açúcar: eficiência e contribuição da inoculação com bactérias diazotróficas. Tese (Doutorado em Agronomia, Ciência do Solo). Universidade Federal Rural do Rio de Janeiro, Seropédica, RJ. 
Smit, M. A., \& Singels, A. (2006). The response of sugarcane canopy development to water stress. Field Crops Research, 98(2-3), 91-97. https://doi.org/10.1016 / j.fcr.2005.12.009

Souza, A. G., \& Cleps, Jr. J. (2009). O desenvolvimento da agroindústria canavieira no Triângulo Mineiro e seus impactos sobre a mão-de-obra e a produção de alimentos. In Encontro Nacional de Geografia Agrária - ENGA (p. 19). São Paulo. Anais... São Paulo: USP.

Trevisan, J. E., Lima, N. C., \& Souza, G. H. S. (2017). Custo da produção da cana de açúcar em uma usina sucroalcooleira da região do Triângulo Mineiro. Revista de estudos contábeis, Londrina, 8(14), 39-57.

Unica. (2013). União da indústria de cana-de-açúcar. Retrieved from http://www.unica.com.br/linha-do-tempo.php

Verma, L. K., \& Solanki, A. (2020). Cost and Returns Analysis of Sugarcane Production in Baghpat district of Western Uttar Pradesh, India. International Journal of Current Microbiology and Applied Sciences, 9(1), 733-739. https://doi.org/10.20546/ijcmas.2020.901.080

Zilio, L. B., \& Lima, R. A. S. (2015). Atratividade de canaviais paulistas sob a ótica da teoria das opções reais. RESR, Piracicaba-SP, 53(03), 377-394. http://doi.org/10.1590/1234-56781806-9479005303001 